\title{
ОСОБЕННОСТИ СЕКРЕЦИИ АДИПОНЕКТИНА И АРИТМИИ У МУЖЧИН С АНДРОИДНЫМ ОЖИРЕНИЕМ
}

Панова Е.И., Цыпленкова Н.С., Стронгин Л.Г.

ГБОУ ВО «Приволжский исследовательский медицинский университет» Минздрава России, Нижний Новгород

ЦЕЛЬ: изучить характер секреции адипонектина у мужчин трудоспособного возраста с ОЖ в сопоставлении с особенностями сердечного ритма.

МАТЕРИАЛЫ И МЕТОДЫ: обследовано 98 пациентов-мУЖчин трудоспособного возраста (средний


Обследование, помимо стандартного клинического, включило оценку ритма сердца с помощью ЭКГ покоя и холтеровского мониторирования ЭКГ (ЭКГ-МТ), ЭХОКГ с оценкой общепринятых параметров, исследование уровня адипонектина (А). Для оценки функционального класса хронической сердечной недостаточности (ФК ХСН) проводился тест 6-минутной ходьбы. Статистическая обработка данных проведена с помощью пакета программ «Statistica 6.0» MicrosoftExel 7.0 для Windows XP с использованием непараметрических методов.

РЕЗУЛЬТАТЫ: средний уровень адипонектинемии у наших пациентов значимо не различался в зависимости от наличия и отсутствия аритмий. Так, у лиц с нормальным ритмом сердца он составил $12,7 \pm 8,6$ мкг/мл, при наличии аритмий, суправентрикулярных и желудочковых, 13,5 $22,2, p=0,84$. В то же время корреляционный анализ показал наличие прямой статистически значимой связи аритмий с адипонектинемией: так, количество ЖЭ в целом за сутки коррелировало с содержанием адипонектина $(\mathrm{r}=+0,34$, $p=0,043)$.

Существенно, что повышенный (превышающий референсные значения) уровень А ассоциировался с наличием XCH. Так, среди пациентов с высоким уровнем гормона ХCH имели $51,7 \%$, с низким уровнем $-33,3 \%, p=0,121$. Эта зависимость становилась достоверной при выделении пациентов с функциональным классом (ФК) XСН II и III. Так, среди лиц с высоким уровнем адипонектина XСН ФК II-III имели 31,0\% пациентов, с низким уровнем - 7,1\%, pх2=0,008; коэффициент ассоциации этих состояний оказался высоким $+0,71$. Дальнейший анализ показал, что количество желудочковых экстрасистол (ЖЭ) в целом за сутки коррелировало не только с уровнем адипонектина, но и с фракцией выброса (ФВ) $(r=-0,35, p=0,004)$, снижение которой, по данным исследований, может являться фактором риска аритмий.

ВЫВодЫ: нарушение секреции А у лиц с ОЖ имеет неоднозначный характер. У лиц со сниженной ФВ и наличием XCH повышенный уровень А ассоциирован с большей частотой желудочковых аритмий. 